\title{
Synthesis, Spectroscopic Studies and Biological Activities of Mixed Metal (III) Complexes of Uracil with 1, 10- Phenanthroline
}

\author{
Shatha M. H.Obaid
}

Department of Chemistry, Education College of Pure Science - Ibn Al-Haithem, University of Baghdad, Baghdad, Iraq.

E-mail: shathaobaid@yahoo.com

Received 7/3/2017

Accepted 25/5/2017

cC) (7)

This work is licensed under a Creative Commons Attribution 4.0 International License.

\begin{abstract}
:
New complexes of the $\left[\mathrm{M}(\mathrm{Ura})(\mathrm{Phen})\left(\mathrm{OH}_{2}\right) \mathrm{Cl}_{2}\right] \mathrm{Cl} .2 \mathrm{H}_{2} \mathrm{O}$ type, where (Ura) uracil ; (Phen) 1,10-phenanthroline hydrate; $\mathrm{M}\left(\mathrm{Cr}^{+3}, \mathrm{Fe}^{+3}\right.$ and $\left.\mathrm{La}^{+3}\right)$ were synthesized from mix ligand and characterized. These complexes have been characterized by the elemental micro analysis, spectral (FT-IR., UV-Vis, ${ }^{1} \mathrm{HNMR},{ }^{13} \mathrm{CNMR}$ and Mass) and magnetic susceptibility as well the molar conductive mensuration. $\mathrm{Cr}^{+3}, \mathrm{Fe}^{+3}$ and $\mathrm{La}^{+3}$ - complexes of six-coordinated were proposed for the insulated for three metal(III) complexes for molecular formulas following into uracil property and 1,10phenanthroline hydrate present . The proposed molecular structure for all metal (III) complexes is octahedral geometries .The biological activity was tested of metal(III) salts, ligands as well as metal(III) complexes to the pathogenic bacteria as well as the antifungal activity has been studied .
\end{abstract}

Key words: Uracil, 1, 10-Phenanthroline hydrate, Metal complexes, Spectral studies, Biological activities .

\section{Introduction:}

Uracil (Ura) a colorless, a planar, and crystalline organic compound of the pyrimidine family. The Ura is one of four nitrogenous bases back to RNA molecule: Ura is cytosine (derivative to pyrimidine), adenine and guanine (derivative to urine). Ura is also a component of coenzymes that act in conjunction with enzymes in operation of carbohydrate metabolism [1-2]. Primarily posted discovery in 1900 , secluded from before hydrolysis of leaven nuclei which is located in cows thymus and spleen, herring sperm [3]. Ura can be used for drug receipt and as a pharmaceutical as materials [4-5], such as 5-fluorouracil is an anticancer drug used to masquerade as Ura during the nucleic acid replication process [6], as well as orotic acid (vitamin $\mathrm{B}_{13}$ ) is the basic intermediate in synthesis of nucleic acids. The being only precursor at the way to form all pryimidine nucleotides in living creatures. Vitamin " $\mathrm{B}_{13}$ " plays as a primary role at metabolism of vitamin " $\mathrm{V}_{6}$ " (folic acid) 
and vitamin $\mathrm{B}_{12}$ (cobalamine), as well as orotic acid has attracted increasing interest in the field medicine [7].

Considerable interest is being evinced in the phenomenon of metal chelation in biological systems. Many of metal ions transition metal complexes with Ura such as the interaction of $\mathrm{Fe}(\mathrm{II}), \mathrm{Co}$ (II), $\mathrm{Ni}(\mathrm{II}), \mathrm{Cu}(\mathrm{II}), \mathrm{Zn}$ (II) and $\mathrm{Cd}(\mathrm{II})$ with Ura [8] and its derivatives complexes [9] .

In lanthanide complexes at different kinds from multi ligand, the metal may be investigated altitude coordination number allowing structural formula the variation responsibility them significant characteristics and their uses in diagnostic medicinal and laser technology [10] .

1,10- phenanthroline (Phen) is a wellknown complexing agent which forms a multitude of coordination with various metal ions [11] . Complexes of Phen at metal ions(III) are pointed out their high composition constants in aqueous solution and sometimes to high molar absorbance. It is worth mentioning the tris-phen iron (II) complex that finds interest as an indicator at oxidimetry result to its high molar absorbance, its high stability in strongly acid solutions and its reverse high oxidation potential. So Phen use in analytical chemistry as an oxidation-reduction indicator is extensive [12]. Phen ligand and its derivatives have resulted in many interesting structures and applications in biological activities [13-14] .Metal complexes which contain diimine ligands like bipyridine and Phen have acquired significant results of their many-sided roles accordingly constructing blocks into installation of metallo-dendrimers and molecular scaffolding into supramolecular collecting and in analytical chemistry, catalysis, electrochemistry, ring-opening qualified change the situation polymerized as well biochemistry [15$16]$.
In the present paper, the synthesis, physical spectroscopic properties of the $\mathrm{Cr}^{+3}, \mathrm{Fe}^{+3}$ and $\mathrm{La}^{+3}$ complexes of mixed ligands (Ura and Phen) and the present work deals with the study of the antibacterial and antifungal of these reported compounds.

\section{Materials and Methods:}

Chemical: Uracil and 1,10Phenanthroline hydrate were parchased, metals(III) chloride as well solvents solution of (Merck, B.D.H. and Riedel). The reagents have been utilized without moreover refining.

Instruments: The measured molar conduct values $(\Lambda \mathrm{m})$ at DMF solution to the metal (III) complexes were measured at $25^{\circ} \mathrm{C}$ with $\left(10^{-3} \mathrm{M}\right)$ solution of the samples which uses PW9527 Digital Conductivity Meter (Philips) .

The infrared (FT.IR) spectra have been registered at $\left(4000-400 \mathrm{~cm}^{-1}\right.$ rang of ligands and (4000-200) $\mathrm{cm}^{-1}$ rang of metal complexes on a Shimadzu IR-470 Spectrum used $\mathrm{KBr}$ and CsI pellts .

The electric spectrum from the complexes in DMF solution $\left(10^{-3}\right)$ were follwed during $25{ }^{\circ} \mathrm{C}$ in the (300-700) $\mathrm{nm}$ rang for a Shimadzu-U.V160.Ultraviolet spectrometer at $1.000 \pm 0.001 \mathrm{~cm}$ matched quartiz cell .

The $\mathrm{C}, \mathrm{H}$ as well $\mathrm{N}$ elements to the complexes were nominated through the micro analytical unit at Eurverctor EA 3000A Elemental Analyzer. When metal (III) contents of the complexes have been identified from before Atomic Absorption (A.A)Technique / Flame Emission Spectrophotometer using AA - 680 Shimadzu .

Magnetic susceptibility mensuration was measured through utilizing the Bruker magnet BM6 apparatus at 298K dependent the Faraday's procedure .

Melting points was determined by using the Stuart Scientific melting point instrument . The ${ }^{1} \mathrm{HNMR}$ and ${ }^{13} \mathrm{CNMR}$ for complexes were recorded by NMR 
bruker500mhz in DMSO- $\mathrm{d}_{6}$ with TMS as the internal standard. Mass spectra were recorded by the 5975C VL MSD with Triple -Axis Detector by the analyzer Quadrupole at $230{ }^{\circ} \mathrm{C}$.

Synthesis metal (III) complexes :The next public steps were adopted into the composition of the complexes:

Uracil solution: Dissolve [0.112gm, $1 \mathrm{mmol}]$ in $5 \mathrm{ml}$ warm water and added $[0.04 \mathrm{gm}, 1 \mathrm{mmol}]$ of the sodium hydroxide .

1,10- Phenanthroline hydrate solution : Dissolve [0.198gm,1mmol] in $5 \mathrm{ml}$ methanol .

Synthesis of complexes : The complexes were prepared by adding of the Phen solution as well Ura solution to the hot water solution to the particular metal chlorides of $\mathrm{CrCl}_{3} \cdot 6 \mathrm{H}_{2} \mathrm{O}$ [0.267gm, $1 \mathrm{mmol}] \mathrm{FeCl}_{3} \quad[0.162 \mathrm{gm}$, $1 \mathrm{mmol}]$, and $\mathrm{LaCl}_{3} .7 \mathrm{H}_{2} \mathrm{O} \quad[0.371 \mathrm{gm}$, $1 \mathrm{mmol}]$ in the stoichiometric ratio metal: ligand (M:Ura:Phe). The mixtures were heated on a water bath to reflux for 12 hours except $\mathrm{Cr}^{+3}$ complex for 24 hour at $70{ }^{0} \mathrm{C}$. The metal complexes were crystal residues observed. The precipitated complexes then were refined off and washed with ether followed by drying at room temperature and analyzing employing standared methods .

Study of biological activity: The activity of microbes from the metal(III) salts, ligands as well metal(III) complexes were examined by agar well - spread method. The antibacterial action of the metal (III) salts, ligands and the identical complexes were checked with each other against Gram positive bacteria $\left(\mathrm{G}^{+} \mathrm{ve}\right)$, (Staphylococcus and Bacillus) and Gram negtive bacteria $\left(\mathrm{G}^{-} \mathrm{ve}\right)$, (E.Coli and
Pseudomonas) and the antifungal activity against the pathogenic Candida (Yeast) by means of nutritions agar well - diffusion method .

The solvent utilized for working exam samples and level was DMSO, which was considered the best solvent in biological effects study [17] and sample of $(1-200 \mu \mathrm{g} / \mathrm{ml})$ were utilized. antimicrobial activity of any compound were estimated by means of the welldiffusion method. $1 \mathrm{~cm} 3$ at a $24 \mathrm{~h}$ broth the culture including $106 \mathrm{CFU} / \mathrm{cm} 3$ was placed in sterilized Petri-dishes.Molten nutritious agar $\left(15 \mathrm{~cm}^{3}\right)$ was kept in ca. $45^{\circ} \mathrm{C}$ and teeming in the Petri-dishes and pliable into stiffen. Other holes of $6 \mathrm{~mm}$ diameter were punctured accurately employing a sterilized cork borer and these were perfectly stuffed for the exam solutions. The dishes were brood into $24 \mathrm{~h}$ within $37^{\circ} \mathrm{C}$.

\section{Results and Discussion:}

The analytical informations and some of the physical characteristics are collected in Table (1). $\mathrm{La}^{+3}$ - complex is colorless, while, the $\mathrm{Cr}^{+3}$ and $\mathrm{Fe}^{+3}$ complexes are colored. The complexes dissolvable in water, DMF and DMSO, but slight dissolvable in $\mathrm{CH}_{3} \mathrm{Cl}, \mathrm{CCl}_{4}$, $\mathrm{CH}_{3} \mathrm{OH}, \mathrm{C}_{2} \mathrm{H}_{5} \mathrm{OH}$ and $\mathrm{C}_{6} \mathrm{H}_{6}$, while non soluble in ether. The elemental analysis information (Table.1) of metal(III) complexes are proportionate for their generic form like 1:1:1 mixed ligand complexes to the species [M(Ura)(Phen) $\left.\left(\mathrm{OH}_{2}\right) \mathrm{Cl}_{2}\right] \mathrm{Cl} .2 \mathrm{H}_{2} \mathrm{O}$. The molar conduct values of the complexes during DMF in $10^{-3} \mathrm{M}$ concentricity and the type of electrolyte for each compound could be determined [18] . 
Table 1: Some Physical Properties and analytical to the Ligands and Complexes

\begin{tabular}{|c|c|c|c|c|c|c|c|c|c|c|c|c|c|}
\hline \multirow{3}{*}{ 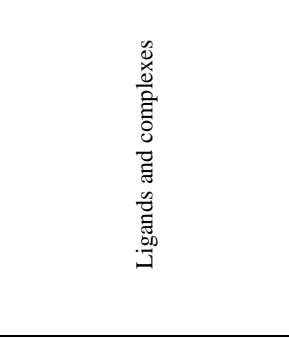 } & \multirow[t]{3}{*}{ 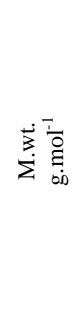 } & \multirow[t]{3}{*}{$\frac{0}{0}$} & \multirow[t]{3}{*}{ ن } & \multirow[t]{3}{*}{ பّ } & \multicolumn{8}{|c|}{ 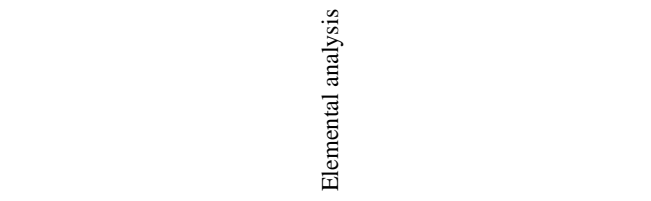 } & \multirow[t]{3}{*}{ 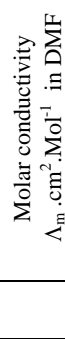 } \\
\hline & & & & & \multicolumn{2}{|c|}{$\% \mathrm{C}$} & \multicolumn{2}{|c|}{$\% \mathrm{H}$} & \multicolumn{2}{|c|}{$\% \mathrm{~N}$} & \multicolumn{2}{|c|}{$\%$ tal } & \\
\hline & & & & & $\begin{array}{c}\text { Calc } \\
.\end{array}$ & $\begin{array}{c}\text { Fou } \\
\text { n. }\end{array}$ & $\begin{array}{c}\mathrm{Cal} \\
\text { c. }\end{array}$ & $\begin{array}{c}\text { Fou } \\
\text { n. }\end{array}$ & $\begin{array}{c}\text { Calc } \\
.\end{array}$ & $\begin{array}{c}\text { Fou } \\
\text { n. }\end{array}$ & Calc & $\begin{array}{c}\text { Fou } \\
\text { n. }\end{array}$ & \\
\hline $\mathrm{C}_{4} \mathrm{H}_{4} \mathrm{~N}_{2} \mathrm{O}_{2}$ & $\begin{array}{c}112.0 \\
9\end{array}$ & White & 335 & - & - & - & - & - & - & - & - & - & $\begin{array}{c}17.9 \\
4 \\
\end{array}$ \\
\hline $\mathrm{C}_{12} \mathrm{H}_{8} \mathrm{~N}_{2} \cdot \mathrm{H}_{2} \mathrm{O}$ & $\begin{array}{c}198.2 \\
2\end{array}$ & White & 97 & - & - & - & - & - & - & - & - & - & 4.18 \\
\hline $\begin{array}{c}{\left[\mathrm{Cr}(\text { Ura })(\text { Phen })\left(\mathrm{OH}_{2}\right) \mathrm{Cl}_{2}\right] \mathrm{Cl} .} \\
2 \mathrm{H}_{2} \mathrm{O}\end{array}$ & 505 & $\begin{array}{l}\text { Dark- } \\
\text { Green }\end{array}$ & - & $>250$ & $\begin{array}{c}38.0 \\
7\end{array}$ & $\begin{array}{c}40.4 \\
5\end{array}$ & 3.59 & 4.76 & $\begin{array}{c}11.1 \\
0\end{array}$ & $\begin{array}{c}12.6 \\
9\end{array}$ & $\begin{array}{c}10.3 \\
0\end{array}$ & $\begin{array}{c}10.5 \\
1\end{array}$ & 79.7 \\
\hline $\begin{array}{c}{\left[\mathrm{Fe}(\mathrm{Ura})(\mathrm{Phen})\left(\mathrm{OH}_{2}\right) \mathrm{Cl}_{2}\right] \mathrm{Cl}} \\
2 \mathrm{H}_{2} \mathrm{O}\end{array}$ & 508 & $\begin{array}{c}\text { Brown } \\
- \\
\text { Raddi } \\
\text { sh } \\
\end{array}$ & - & $>250$ & $\begin{array}{c}37.8 \\
3\end{array}$ & $\begin{array}{c}40.5 \\
9\end{array}$ & 3.57 & 4.99 & $\begin{array}{c}11.3 \\
0\end{array}$ & $\begin{array}{c}11.6 \\
1\end{array}$ & $\begin{array}{c}10.8 \\
6\end{array}$ & $\begin{array}{c}12.1 \\
9\end{array}$ & 65.4 \\
\hline $\begin{array}{c}{\left[\mathrm{La}(\text { Ura })(\text { Phen })\left(\mathrm{OH}_{2}\right) \mathrm{Cl}_{2}\right] \mathrm{Cl}} \\
2 \mathrm{H}_{2} \mathrm{O}\end{array}$ & 592 & White & - & $>250$ & $\begin{array}{c}32.4 \\
8\end{array}$ & $\begin{array}{c}32.4 \\
9\end{array}$ & 3.07 & 3.26 & 9.47 & $\begin{array}{c}10.6 \\
8\end{array}$ & - & - & 40.1 \\
\hline
\end{tabular}

* M.P = melting point

* * Dec. $=$ Decomposition temperature

\section{Infra - red Spectra:}

The features frequencies of the ligands and complexes of the metals (III) are set in Table (2) for each of ligands and metal(III) - complexes and the Cr(III)complex in Figure 1. For each of ligands and $\mathrm{Cr}^{+3}$ - complex. The broad band appearing in the (3390-3414) $\mathrm{cm}^{-1}$ and (3109-3113) $\mathrm{cm}^{-1}$ areas in each of the complexes are refered into the $-\mathrm{OH}$ streching vibration at hydrated as well coordinated $\mathrm{H}_{2} \mathrm{O}$ molecules [19] and hydrogen bonds of the type

$\mathrm{N}$ - H --- O [20] . Furthermore, The occurrence of a strong band in the rang $(848-852) \mathrm{cm}^{-1}$ in the IR spectra of the complexes, whom is assignable to the $\mathrm{OH}$ rocking vibration, confirms the presence of coordinated water [21].

The absorption frequencies of the metal (III)- compounds with Ura were contrasted to that of the free Ura in the area between $(1800-1300) \mathrm{cm}^{-1}$ where the $\mathrm{CO}$ and $\mathrm{NH}$ frequency of Ura are existing [22]. The bending vibrations of $\delta \mathrm{NH}_{(1)}$ and $\delta \mathrm{NH}_{(3)}$ in $1508 \mathrm{~cm}^{-1}$ and $1419 \mathrm{~cm}^{-1}$ of free Ura and in the complexes stick about constant both in intensity and placement in (1508-1519) $\mathrm{cm}^{-1}$ and (1419-1423) $\mathrm{cm}^{-1}$ respectively . The $v\left(\mathrm{C}_{(2)}=\mathrm{O}\right)$ band at $1735 \mathrm{~cm}^{-1}$ and $1716 \mathrm{~cm}^{-1}$ in Ura, which two bands evidenced, but in the complexes evidenced one band with complexes in (1712-1720) $\mathrm{cm}^{-1}$ with disappearance of the second band . The $v\left(\mathrm{C}_{(4)}=\mathrm{O}\right)$ band at $1670 \mathrm{~cm}^{-1}$ and $1643 \mathrm{~cm}^{-1}$ in free Ura, the small vairation in the band situation of the 4-keto group of Ura in the complexes may be due to the hydrogen bonding [23] .

It can be concluded that in metal (III) complexes Ura acts as chelating ligand, the coordination that occurs with the oxygen to the 2-keto group of the Ura with metals (III) .

The $v(\mathrm{C}=\mathrm{N})$ and $(\mathrm{C}=\mathrm{C})$ mode were observed at $1558 \mathrm{~cm}^{-1}$ to the spectra of free Phen ligand are showed to be shifted to lower wave number around (1454-1496) $\mathrm{cm}^{-1}$ to the spectrum from complexes . A negative shift into that vibrational mode at complexes referenced the coordination out of nitrogen donar from Phen with M (III) ions [24] .

The presence of characteristic bands to the coordinated of the metal - oxygen with 2-keto group of the Ura in the $(450-480) \mathrm{cm}^{-1}$ to metal (III)- complexes, which that Ura is monodentate in all the complexes, while the Phen ligand acts as a bidentate ligand all the complexes by coordinating through the metal - 
nitrogen with nitrogen group to the Phen in the $(490-500) \mathrm{cm}^{-1}$ to metal (III)complexes [25]. The $\mathrm{U}(\mathrm{M}-\mathrm{Cl})$ bands are tentatively assigned in the lower region in the (351-366) $\mathrm{cm}-1$ [26] .

Table 2 : FT-IR Spectral Data of the Ligands and their Complexes

\begin{tabular}{|c|c|c|c|c|c|c|c|c|c|c|c|}
\hline Compound & $\begin{array}{c}\mathrm{v}(\mathrm{OH}) \\
\mathrm{H}_{2} \mathrm{O}\end{array}$ & $v(\mathrm{NH})$ & $v(\mathrm{CH})$ & $v\left(C_{(2)}=0\right)$ & $v\left(C_{(4)}=0\right)$ & $\delta \mathrm{NH}_{(\mathbf{1})}$ & $\delta \mathbf{N H}_{(3)}$ & $\begin{array}{c}v(\mathrm{C}=\mathrm{N}) \\
+ \\
(\mathrm{C}=\mathrm{C})\end{array}$ & $v(M-N)$ & $\begin{array}{l}\text { v(M- } \\
\text { O) }\end{array}$ & $v(\mathrm{M}-\mathrm{Cl})$ \\
\hline $\mathrm{C}_{4} \mathrm{H}_{4} \mathrm{~N}_{2} \mathrm{O}_{2}$ & - & 3103br. & $\begin{array}{l}3039 w \\
2985 w\end{array}$ & $\begin{array}{l}1735 w \\
1716 w\end{array}$ & $\begin{array}{l}1670 w \\
1643 w\end{array}$ & $1508 \mathrm{~s}$ & $1419 \mathrm{~s}$ & - & - & - & - \\
\hline $\mathrm{C}_{12} \mathrm{H}_{8} \mathrm{~N}_{2} \cdot \mathrm{H}_{2} \mathrm{O}$ & 3410br. & - & $2993 w$ & - & - & - & - & $1558 \mathrm{~s}$ & - & - & - \\
\hline $\begin{array}{c}\left.\mathrm{Cr}(\text { Ura })(\text { Phen })\left(\mathrm{OH}_{2}\right) \mathrm{Cl}_{2}\right] \mathrm{Cl} . \\
2 \mathrm{H}_{2} \mathrm{O}\end{array}$ & 3414br. & 3109br. & $\begin{array}{l}2992 w \\
2935 w\end{array}$ & $1712 \mathrm{~s}$ & $\begin{array}{l}1670 \mathrm{~s} \\
1652 \mathrm{w}\end{array}$ & $1519 \mathrm{~s}$ & $1423 \mathrm{~s}$ & $1496 w$ & $547 w$ & $435 w$ & $366 \mathrm{w}$ \\
\hline $\begin{array}{c}\left.\mathrm{Fe}(\mathrm{Ura})(\mathrm{Phen})\left(\mathrm{OH}_{2}\right) \mathrm{Cl}_{2}\right] \mathrm{Cl} . \\
2 \mathrm{H}_{2} \mathrm{O}\end{array}$ & 3396br. & 3113br. & $\begin{array}{l}3043 w \\
2985 w\end{array}$ & $1720 \mathrm{~s}$ & $\begin{array}{l}1662 w \\
1647 w\end{array}$ & $1512 \mathrm{~s}$ & $1419 \mathrm{~s}$ & $1454 \mathrm{~s}$ & $543 w$ & $428 w$ & $354 w$ \\
\hline $\begin{array}{c}\left.\mathrm{La}(\text { Ura })(\text { Phen })\left(\mathrm{OH}_{2}\right) \mathrm{Cl}_{2}\right] \mathrm{Cl} . \\
2 \mathrm{H}_{2} \mathrm{O}\end{array}$ & 3390br. & 3113br. & $\begin{array}{l}3047 w \\
2989 w\end{array}$ & $1716 \mathrm{~s}$ & $\begin{array}{l}1662 w \\
1651 w\end{array}$ & $1508 w$ & 1419s & $1454 w$ & $543 w$ & $435 w$ & $351 w$ \\
\hline
\end{tabular}

$\begin{array}{lll}\mathrm{s}=\text { sharp } & \text { br. }=\text { broad } & \mathrm{w}=\text { weak }\end{array}$

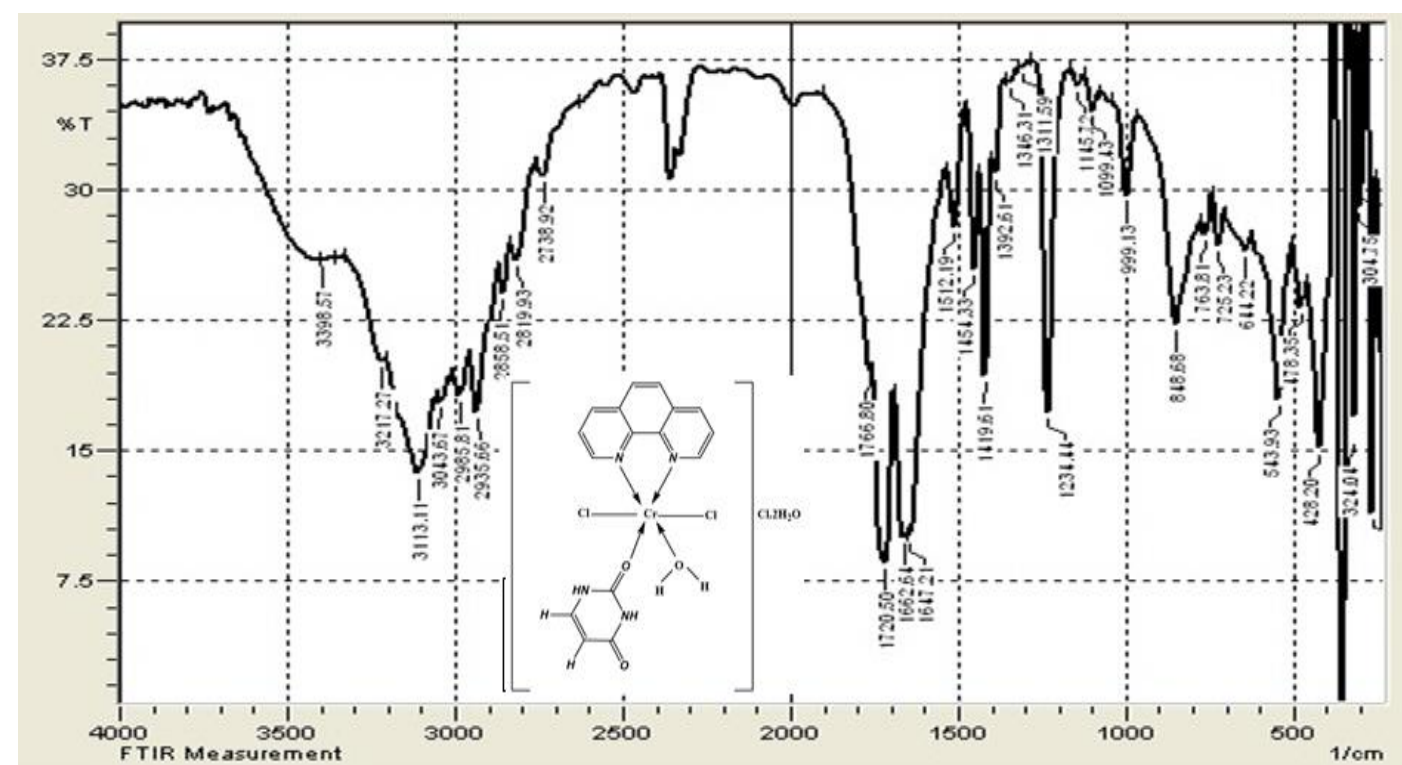

Fig1. FT.IR spectrum of $\mathrm{Cr}^{+3}$ - complex

\section{Ultraviolet-Visible Spectroscopy:}

The electronic spectrum to the ligand and metal (III)- complexes were listed at DMF as indicated in Table 3. and Figure 2. For each of ligands and $\mathrm{Cr}^{+3}$ complex. The Ultraviolet-Visible spectrum to the free ligand Ura displayed two absorption bands at $270 \mathrm{~nm}\left(37037 \mathrm{~cm}^{-1}\right)$ and 320 $\mathrm{nm}\left(31250 \mathrm{~cm}^{-1}\right)$ refered to $\left(\pi-\pi^{*}\right)$ and $\left(\mathrm{n}-\pi^{*}\right)$ transition of the carbonyl group, however the later to the conforming transition of $\mathrm{N}=\mathrm{C}=\mathrm{O}$ chromophore [27] and the spectrum of the free ligand (Phen) display absorption peak in 270 $\mathrm{nm}\left(37037 \mathrm{~cm}^{-1}\right), 301 \mathrm{~nm}\left(33222.6 \mathrm{~cm}^{-1}\right)$ and $324 \mathrm{~nm}\left(30864 \mathrm{~cm}^{-1}\right)$, that indicated into $\left(\pi-\pi^{*}\right),\left(\mathrm{n}-\pi^{*}\right)$ and $\left(\mathrm{n}-\pi^{*}\right)$ transition Consecutively, which transmits the pyridine rings [28].
The electronic spectra of six coordinated $\mathrm{Cr}^{+3}$ - complex exhibited two absorption bands $654 \mathrm{~nm}\left(15290 \mathrm{~cm}^{-1}\right)$ and $443 \mathrm{~nm}$ $\left(22573 \mathrm{~cm}^{-1}\right)$ due to ${ }^{4} \mathrm{~A}_{2 \mathrm{~g}} \rightarrow{ }_{4} \mathrm{~T}_{1 \mathrm{~g}}(\mathrm{~F})$ and ${ }^{4} \mathrm{~A}_{2 \mathrm{~g}} \rightarrow{ }^{4} \mathrm{~T}_{2 \mathrm{~g}}(\mathrm{~F})$ recpectively and the two band expected $322 \mathrm{~nm}\left(31055 \mathrm{~cm}^{-1}\right)$ and $269 \mathrm{~nm}\left(37174 \mathrm{~cm}^{-1}\right)$, overlaps with the ligand bands or charge transfer (LMCT) [29]. The chromium (III)- complex shows $\mu_{\text {eff }}$ values 3.87 B.M. comforming to three unpaired electrons, which suggests a high spin to octahedral stereochemistry [30].

The electric spectrum of the $\mathrm{Fe}^{+3}$ complex shows three absorption bands at $450 \mathrm{~nm}\left(22222.0 \mathrm{~cm}^{-1}\right)$ due to ${ }^{6} \mathrm{~A}_{1 \mathrm{~g}}$ $\rightarrow{ }^{4} \mathrm{~T}_{2 \mathrm{~g}}(\mathrm{G})$ and the four absorption bands at $364 \mathrm{~nm}(274723 \mathrm{~cm}-1)$ due to the presence of a charge transfer (LMCT), 
which obscures the low indensity $\mathrm{d}-\mathrm{d}$ absorption bands and $345 \mathrm{~nm}, 328 \mathrm{~nm}$ and $270 \mathrm{~nm}(28985, \quad 30487.0$ and $37037.0 \mathrm{~cm}^{-1}$ ) which assigned to ligand field (L.F). The magnetic moment amount of this complex was got 6.31 B.M., which was very near the value of octahedral spatial structure of high spin state [31] .
In the spectrum of the $\mathrm{La}^{+3}$ - complex of six coordinated exhibited one absorption band at $403 \mathrm{~nm}$

$\left(24813.0 \mathrm{~cm}^{-1}\right)$ in the UV-Vis region caused by charge transfer (LMCT) at $269 \mathrm{~nm}(37174.0 \mathrm{~cm}-1)$ and $322 \mathrm{~nm}$ $\left(31055.0 \mathrm{~cm}^{-1}\right)$ and $325 \mathrm{~nm}\left(30769 \mathrm{~cm}^{-1}\right)$ in the UV-Vis region overlaps with the ligand bands [32].Figure 3. suggests the framework and 3D-geometrical structure of the metal (III) - Complexes .

Table 3 : Electronic Spectra to the Ligands and Complexes

\begin{tabular}{|c|c|c|c|c|}
\hline Ligands and complexes & $\lambda_{\max }(\mathbf{n m})$ & $\begin{array}{c}\text { Wave Number } \\
v\left(\mathrm{~cm}^{-1}\right)\end{array}$ & $\mathbf{E}_{\max }$ & Assignment \\
\hline $\mathrm{C}_{4} \mathrm{H}_{4} \mathrm{~N}_{2} \mathrm{O}_{2}$ & $\begin{array}{l}270 \\
320\end{array}$ & $\begin{array}{l}37037.0 \\
31250.0\end{array}$ & $\begin{array}{l}1213 \\
1126\end{array}$ & $\begin{array}{l}\boldsymbol{\pi} \rightarrow \pi^{*} \\
\mathbf{n} \rightarrow \pi^{*}\end{array}$ \\
\hline $\mathrm{C}_{12} \mathrm{H}_{8} \mathrm{~N}_{2} \cdot \mathrm{H}_{2} \mathrm{O}$ & $\begin{array}{l}270 \\
301 \\
324 \\
\end{array}$ & $\begin{array}{l}37037.0 \\
33222.5 \\
\text { 30864.0 } \\
\end{array}$ & $\left.\begin{array}{c}1135 \\
845 \\
1139\end{array}\right\}$ & $\begin{array}{c}\boldsymbol{\pi} \rightarrow \pi^{*} \\
\pi^{*} \rightarrow \mathbf{n}\end{array}$ \\
\hline$\left[\mathrm{Cr}(\mathrm{Ura})(\mathrm{Phen})\left(\mathrm{OH}_{2}\right) \mathrm{Cl}_{2}\right] \mathrm{Cl} .2 \mathrm{H}_{2} \mathrm{O}$ & $\begin{array}{l}\mathbf{2 6 9} \\
322 \\
443 \\
654\end{array}$ & $\begin{array}{l}37174.0 \\
31055.0 \\
22573.0 \\
15290.0\end{array}$ & $\begin{array}{c}1176 \\
919 \\
63 \\
30\end{array}$ & $\begin{array}{c}\text { L.F } \\
\text { L.F }+ \text { C.T } \\
{ }^{4} \mathbf{A}_{2 \mathrm{~g}} \rightarrow{ }^{4} \mathbf{T}_{2 \mathrm{~g}}(\mathbf{F}) \\
{ }^{4} \mathbf{A}_{2 \mathrm{~g}} \rightarrow{ }^{4} \mathbf{T}_{1 \mathrm{~g}}(\mathbf{F})\end{array}$ \\
\hline$\left[\mathrm{Fe}(\right.$ Ura $)($ Phen $\left.)\left(\mathrm{OH}_{2}\right) \mathrm{Cl}_{2}\right] \mathrm{Cl}_{2} \mathrm{H}_{2} \mathrm{O}$ & $\begin{array}{l}270 \\
328 \\
345 \\
364 \\
450\end{array}$ & \begin{tabular}{|l|}
37037.0 \\
30487.0 \\
28985.0 \\
27472.0 \\
22222.0
\end{tabular} & \begin{tabular}{|c|c|}
1265 \\
1508 \\
1619 \\
1013 \\
20
\end{tabular} & $\begin{array}{c}\text { L.F } \\
\text { L.F } \\
\text { L.F } \\
\text { C.T } \\
{ }^{6} \mathbf{A}_{1 \mathrm{~g}} \rightarrow{ }^{4} \mathbf{T}_{2 \mathrm{~g}}(\mathbf{G})\end{array}$ \\
\hline$\left[\mathrm{La}(\mathrm{Ura})(\mathrm{Phen})\left(\mathrm{OH}_{2}\right) \mathrm{Cl}_{2}\right] \mathrm{Cl} .2 \mathrm{H}_{2} \mathrm{O}$ & $\begin{array}{l}269 \\
325 \\
403 \\
891\end{array}$ & $\begin{array}{l}37174.0 \\
30769.0 \\
24813.0 \\
11223.0\end{array}$ & $\begin{array}{c}1067 \\
483 \\
61 \\
2\end{array}$ & $\begin{array}{l}\text { L.F } \\
\text { L.F } \\
\text { C.T } \\
\text { f } \rightarrow \mathbf{f}\end{array}$ \\
\hline
\end{tabular}
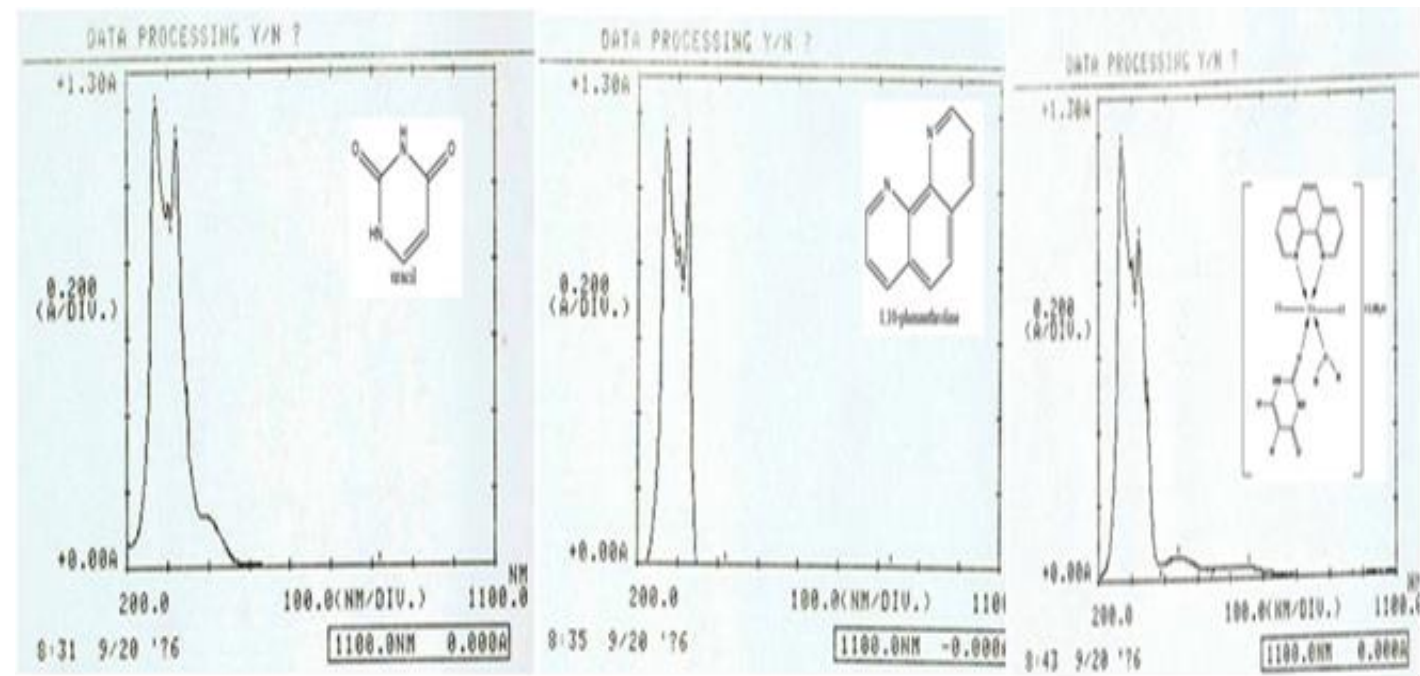

Fig.2. UV spectra of ligands and $\mathrm{Cr}^{+3}$ - complex 


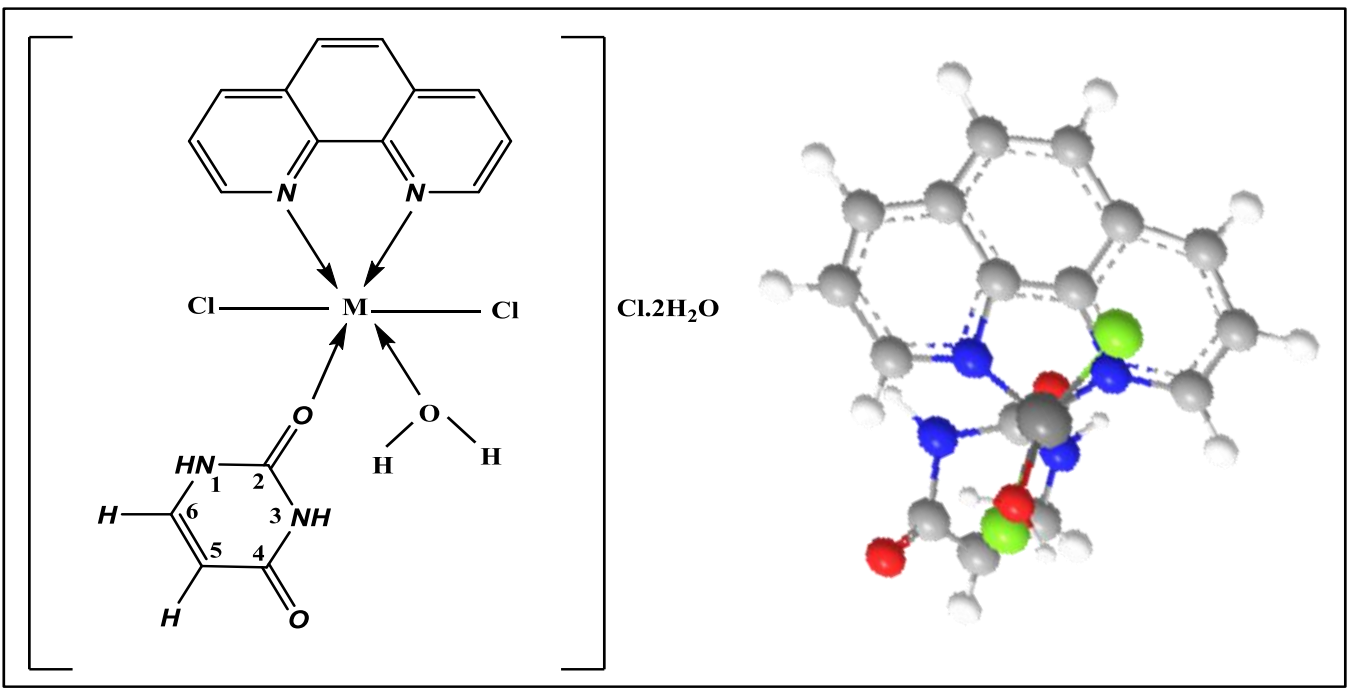

Fig.3. The Proposed Structure and 3D-geometrical structure of the Complexes $\left[\mathrm{M}(\mathrm{Ura})(\mathrm{Phe})\left(\mathrm{OH}_{2}\right) \mathrm{Cl}_{2}\right] \mathrm{Cl} .2 \mathrm{H}_{2} \mathrm{O},\left(\mathrm{M}=\mathrm{Cr}^{+3}, \mathrm{Fe}^{+3}\right.$ and $\left.\mathrm{La}^{+3}\right)$

${ }^{1}$ HNMR spectra ${ }^{13}$ CNMR spectra studies:

The ${ }^{1}$ HNMR spectra of a DMSO- $\mathrm{d}_{6}$ solution as solvent of the complexes in Table 4. and Figure 4. For $\mathrm{Cr}^{+3}$ complex. Shows multiplet signal at $\delta(5.275-9.211 \mathrm{ppm})$ refers to aromatic protons $(10 \mathrm{H})$. On the other hand, the signals at $\delta(10.784-11.136 \mathrm{ppm})(2 \mathrm{H})$ are due to proton of $(\mathrm{NH})$ of Ura group of the metal(III) complexes [33-34]. The signal characteristic to the $\mathrm{NH}$ of Ura ring appeared in the same position indicating that the $\mathrm{NH}$ group of Ura ring did not participate in coordination. Thus the ${ }^{1}$ HNMR results further supports the IR inferences. Whereas, the signal at $\delta 2.5 \mathrm{ppm}$ referred to DMSO- $\mathrm{d}_{6}$. The presence of water molecules in the complexes is confirmed by the appearance of a new signal around $\delta(3.3-3.5 \mathrm{ppm})$, attributed to $\mathrm{H}_{2} \mathrm{O}$ protons [35].

The ${ }^{13}$ CNMR spectra data of the metal(III) complexes. and Figure 5. For $\mathrm{Cr}^{+3}$ - complex. The two peaks at $\delta(150.00$ and 162.791) ppm were assigned to the $\left(\mathrm{C}_{2}\right.$ and $\left.\mathrm{C}_{4}\right)$ of carbonyl group of the Ura ring [33]. There is a simple change in carbonyl group of the Ura ring in all of the complexes, where the two carbonyl groups remained unchanged at the complexs formation, also support the authenticity of the proposed structures of the three complexes. The signals to the carbon of Ura ring and Phen ring are shifted from $\delta(99.109-149.823) \mathrm{ppm}$ and the signal at $\delta 40.296 \mathrm{ppm}$ referred to DMSO- $\mathrm{d}_{6}[36]$.

Table 4: 1HNMR spectra data of the of the three complexes

\begin{tabular}{|c|c|c|c|c|}
\hline Compounds & $\mathrm{Cr}\left(\mathrm{C}_{16} \mathrm{H}_{18} \mathrm{~N}_{4} \mathrm{O}_{5}\right) \cdot \mathrm{Cl}_{3}$ & $\mathrm{Fe}\left(\mathrm{C}_{16} \mathrm{H}_{18} \mathrm{~N}_{4} \mathrm{O}_{5}\right) \cdot \mathrm{Cl}_{3}$ & $\mathrm{La}\left(\mathrm{C}_{16} \mathrm{H}_{18} \mathrm{~N}_{4} \mathrm{O}_{5}\right) \cdot \mathrm{Cl}_{3}$ & Assignment \\
\hline \multirow[t]{2}{*}{$\begin{array}{l}\text { Chemical shift, } \\
(\delta) \mathrm{ppm}\end{array}$} & $(5.424-9.211) \mathrm{s}$ & $(5.275-7.219) \mathrm{s}$ & $(7.390-9.211) \mathrm{s}$ & $\begin{array}{l}10 \mathrm{H}, \\
\text { Aromatic } \\
\text { rings of Ura } \\
\text { and Phen }\end{array}$ \\
\hline & $\begin{array}{c}11.069 \\
11.095 \mathrm{~m}\end{array}$ & $\begin{array}{c}10.784 \\
10.788 \mathrm{~s}\end{array}$ & $\begin{array}{c}11.069 \\
11.095 \mathrm{~m}\end{array}$ & $\begin{array}{l}\mathrm{s}, 2 \mathrm{H}, \mathrm{NH}, \\
\text { Ura ring }\end{array}$ \\
\hline
\end{tabular}




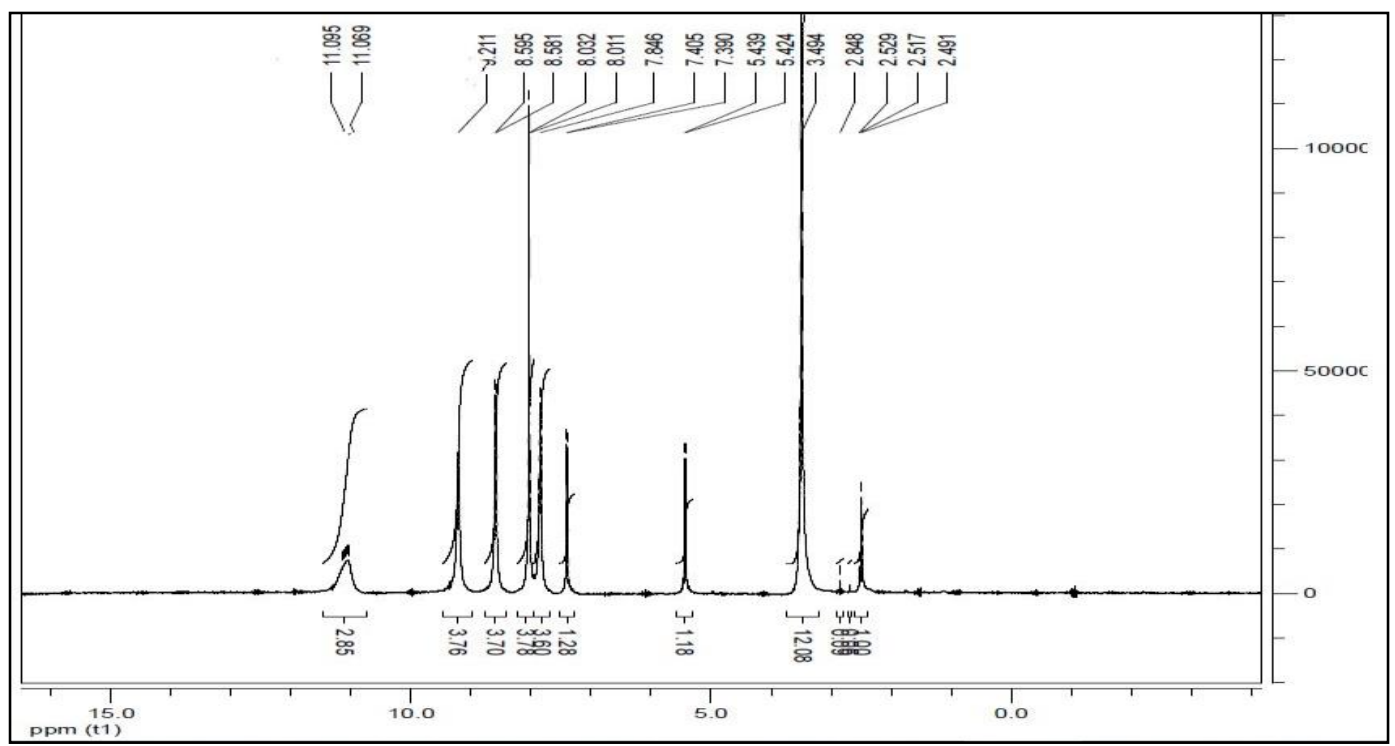

Fig.4. ${ }^{1} \mathrm{HNMR}$ spectrum of the $\mathrm{Cr}^{+3}$-complex

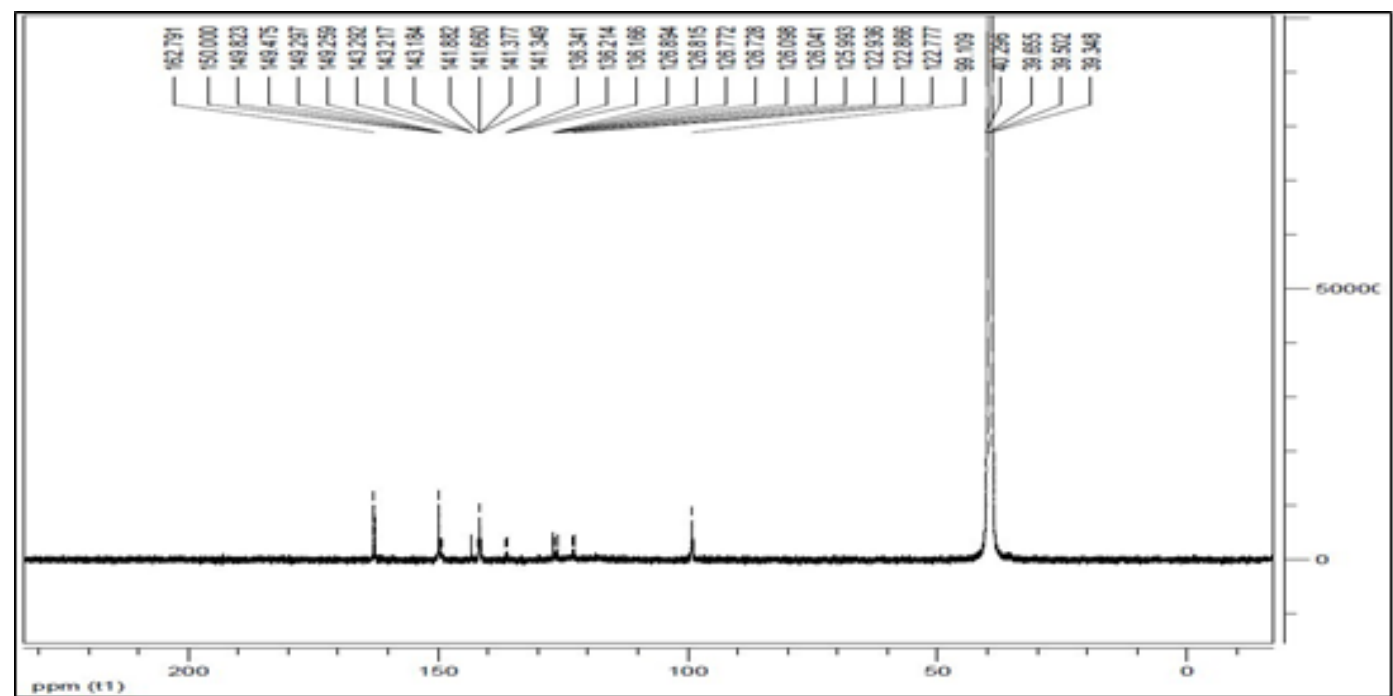

Fig. 5. ${ }^{13} \mathrm{CNMR}$ spectrum of the $\mathrm{Cr}^{+3}$-complex

\section{Mass spectra:}

The mass spectra of Table 5. and Figure (6-8) are for each of $\mathrm{Cr}^{+3}, \mathrm{Fe}^{+3}$ and $\mathrm{La}^{+3}$ complexes, respectively. Displayed peaks refered in the molecular ions $\mathrm{m} / \mathrm{z}$ at 505,508 and 592 $\mathrm{M}^{+}$into $\mathrm{Cr}^{+3}, \mathrm{Fe}^{+3}$ and $\mathrm{La}^{+3}$ complexes, Consecutively. That datum is at good convention for the suggest molecular formulation into the complexes. The mass spectral data backing the structures of transition metal complexes. The fragmentation type to the complexes does not display the loss of one for chlorine and two water molecules, It is exist outside the coordination field one for chlorine and two water molecules [28]. The fragmentation patterns of the studies for $\mathrm{Cr}^{+3}, \mathrm{Fe}^{+3}$ and $\mathrm{La}^{+3}$ complexes, respectively, obtained from the mass spectra are given in Table 5 . The suggested molecular formula of these complexes was provened through resembling their molecular formula weights with $\mathrm{m} / \mathrm{z}$ values. 
Table 5: Mass spectra data of the important mass peaks for the complexes

\begin{tabular}{|c|c|c|c|}
\hline Complexes & Mass assignments & M & $\mathbf{m} / \mathbf{z}$ \\
\hline \multirow{10}{*}{$\mathrm{Cr}\left(\mathrm{C}_{16} \mathrm{H}_{18} \mathrm{~N}_{4} \mathrm{O}_{5} \mathrm{Cl}_{3}\right)$} & {$\left[\mathrm{CrC}_{16} \mathrm{H}_{18} \mathrm{~N}_{3} \mathrm{O}_{4} \mathrm{Cl}_{2}\right]^{+}$} & 439 & 439 \\
\hline & {$\left[\mathrm{CrC}_{15} \mathrm{H}_{18} \mathrm{~N}_{3} \mathrm{O}_{2} \mathrm{Cl}_{2}\right]^{+}$} & 395 & 395 \\
\hline & {$\left[\mathrm{CrC}_{14} \mathrm{H}_{13} \mathrm{NO}_{2} \mathrm{Cl}_{2}\right]^{+}$} & 350 & 350 \\
\hline & {$\left[\mathrm{CrC}_{14} \mathrm{H}_{6} \mathrm{O}_{2} \mathrm{Cl}\right]^{+}$} & 293 & 293 \\
\hline & {$\left[\mathrm{CrC}_{10} \mathrm{H}_{4} \mathrm{O}_{2} \mathrm{Cl}\right]^{+}$} & 243 & 243 \\
\hline & {$\left[\mathrm{CrC}_{6} \mathrm{H}_{4} \mathrm{O}_{2} \mathrm{Cl}\right]^{+}$} & 195 & 195 \\
\hline & {$\left[\mathrm{C}_{5} \mathrm{H}_{4} \mathrm{O}_{2} \mathrm{Cl}\right]^{+}$} & 131 & 131 \\
\hline & {$\left[\mathrm{C}_{3} \mathrm{H}_{4} \mathrm{O}_{2} \mathrm{Cl}\right]^{+}$} & 107 & 107 \\
\hline & {$\left[\mathrm{CH}_{4} \mathrm{O}_{2} \mathrm{Cl}\right]^{+}$} & 83 & 83 \\
\hline & {$\left[\mathrm{H}_{4} \mathrm{O}_{2} \mathrm{Cl}\right]^{+}$} & 71 & 71 \\
\hline \multirow{10}{*}{$\mathrm{Fe}\left(\mathrm{C}_{16} \mathrm{H}_{18} \mathrm{~N}_{4} \mathrm{O}_{5} \mathrm{Cl}_{3}\right)$} & {$\left[\mathrm{FeC}_{16} \mathrm{H}_{15} \mathrm{~N}_{4} \mathrm{O}_{5} \mathrm{Cl}_{3}\right]^{+}$} & 505 & 505 \\
\hline & {$\left[\mathrm{FeC}_{15} \mathrm{H}_{15} \mathrm{~N}_{2} \mathrm{O}_{4} \mathrm{Cl}_{3}\right]^{+}$} & 449 & 449 \\
\hline & {$\left[\mathrm{FeC}_{14} \mathrm{H}_{14} \mathrm{~N}_{2} \mathrm{O}_{4} \mathrm{Cl}_{2}\right]^{+}$} & 400 & 400 \\
\hline & {$\left[\mathrm{FeC}_{11} \mathrm{H}_{14} \mathrm{NO}_{4} \mathrm{Cl}_{2}\right]^{+}$} & 350 & 350 \\
\hline & {$\left[\mathrm{FeC}_{10} \mathrm{H}_{14} \mathrm{NO}_{4} \mathrm{Cl}\right]^{+}$} & 302 & 302 \\
\hline & {$\left[\mathrm{C}_{10} \mathrm{H}_{14} \mathrm{NO}_{3} \mathrm{Cl}\right]^{+}$} & 228 & 228 \\
\hline & {$\left[\mathrm{C}_{6} \mathrm{H}_{14} \mathrm{NO}_{3} \mathrm{Cl}\right]^{+}$} & 180 & 180 \\
\hline & {$\left[\mathrm{CH}_{14} \mathrm{NO}_{3} \mathrm{Cl}\right]^{+}$} & 120 & 120 \\
\hline & {$\left[\mathrm{CH}_{6} \mathrm{NO}_{2} \mathrm{Cl}\right]^{+}$} & 96 & 96 \\
\hline & {$\left[\mathrm{H}_{4} \mathrm{O}_{2} \mathrm{Cl}\right]^{+}$} & 68 & 68 \\
\hline \multirow{9}{*}{$\mathrm{La}\left(\mathrm{C}_{16} \mathrm{H}_{18} \mathrm{~N}_{4} \mathrm{O}_{5} \mathrm{Cl}_{3}\right)$} & {$\left[\mathrm{LaC}_{15} \mathrm{H}_{17} \mathrm{~N}_{4} \mathrm{O}_{5} \mathrm{Cl}_{3}\right]^{+}$} & 579 & 579 \\
\hline & {$\left[\mathrm{LaC}_{15} \mathrm{H}_{14} \mathrm{~N}_{4} \mathrm{O}_{4} \mathrm{Cl}_{2}\right]^{+}$} & 524 & 524 \\
\hline & {$\left[\mathrm{LaC}_{15} \mathrm{H}_{13} \mathrm{~N}_{3} \mathrm{O}_{2} \mathrm{Cl}_{2}\right]^{+}$} & 477 & 477 \\
\hline & {$\left[\mathrm{LaC}_{15} \mathrm{H}_{10} \mathrm{~N}_{2} \mathrm{O}_{2} \mathrm{Cl}\right]^{+}$} & 424 & 424 \\
\hline & {$\left[\mathrm{LaC}_{13} \mathrm{H}_{6} \mathrm{O}_{2} \mathrm{Cl}\right]^{+}$} & 368 & 368 \\
\hline & {$\left[\mathrm{LaC}_{4} \mathrm{H}_{4} \mathrm{O}_{2} \mathrm{Cl}\right]^{+}$} & 258 & 258 \\
\hline & {$\left[\mathrm{C}_{4} \mathrm{H}_{4} \mathrm{O}_{2} \mathrm{Cl}\right]^{+}$} & 119 & 119 \\
\hline & {$\left[\mathrm{CH}_{4} \mathrm{O}_{2} \mathrm{Cl}\right]^{+}$} & 83 & 83 \\
\hline & {$\left[\mathrm{H}_{4} \mathrm{O}_{2} \mathrm{Cl}\right]^{+}$} & 71 & 71 \\
\hline
\end{tabular}
$\mathrm{m} / \mathrm{z} \rightarrow$

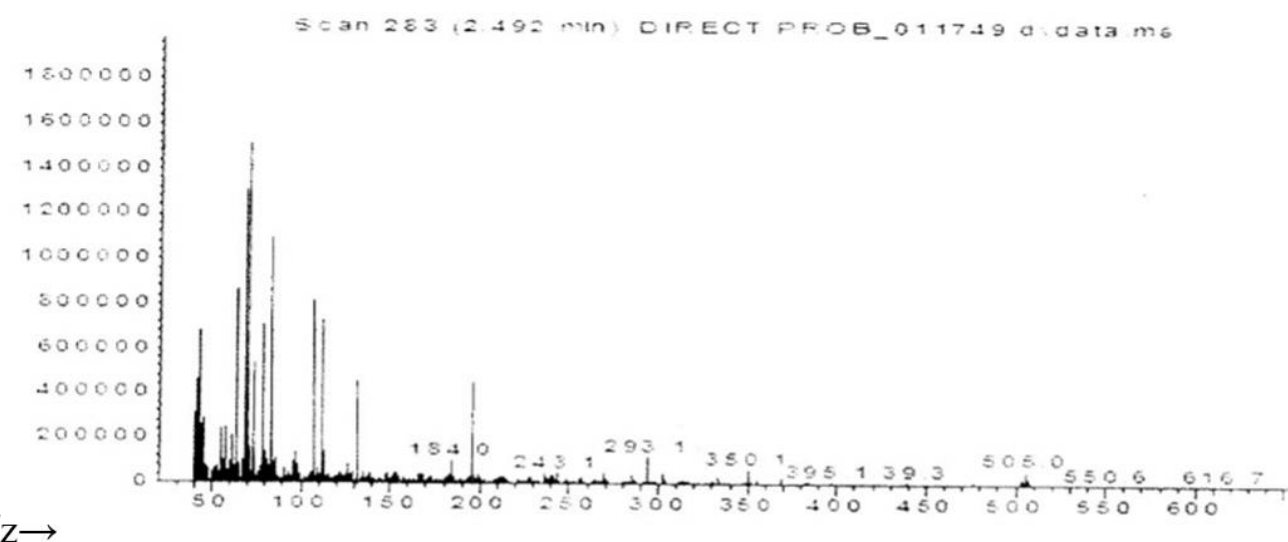

Fig. 6. Mass spectrum of $\mathrm{Cr}^{+3}-$ complex

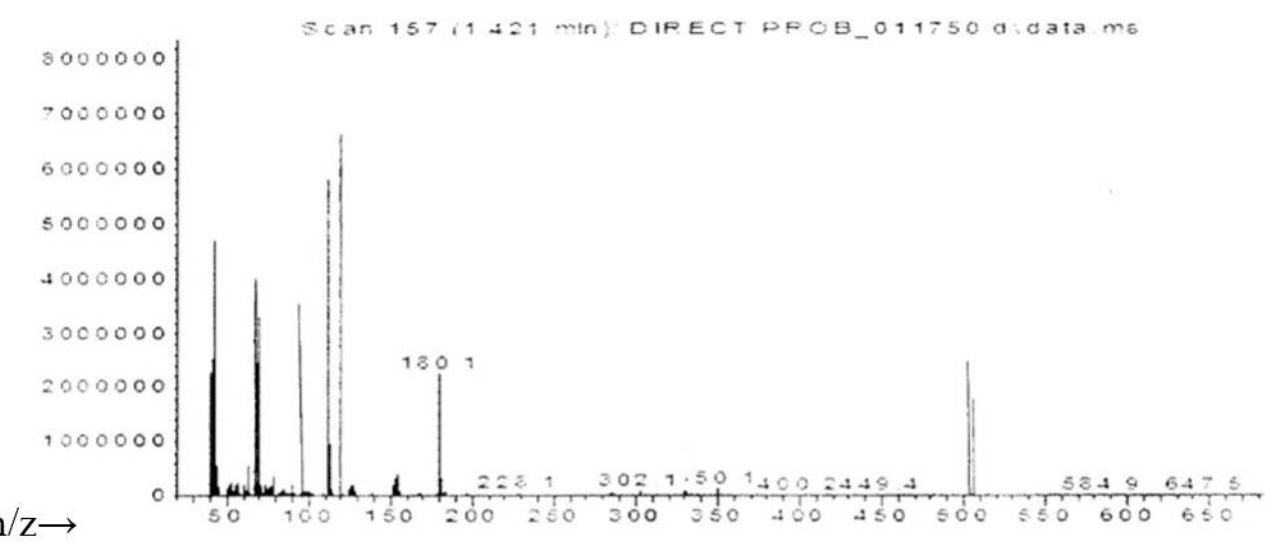

Fig.7. Mass spectrum of $\mathrm{Fe}^{+3}$ - complex 


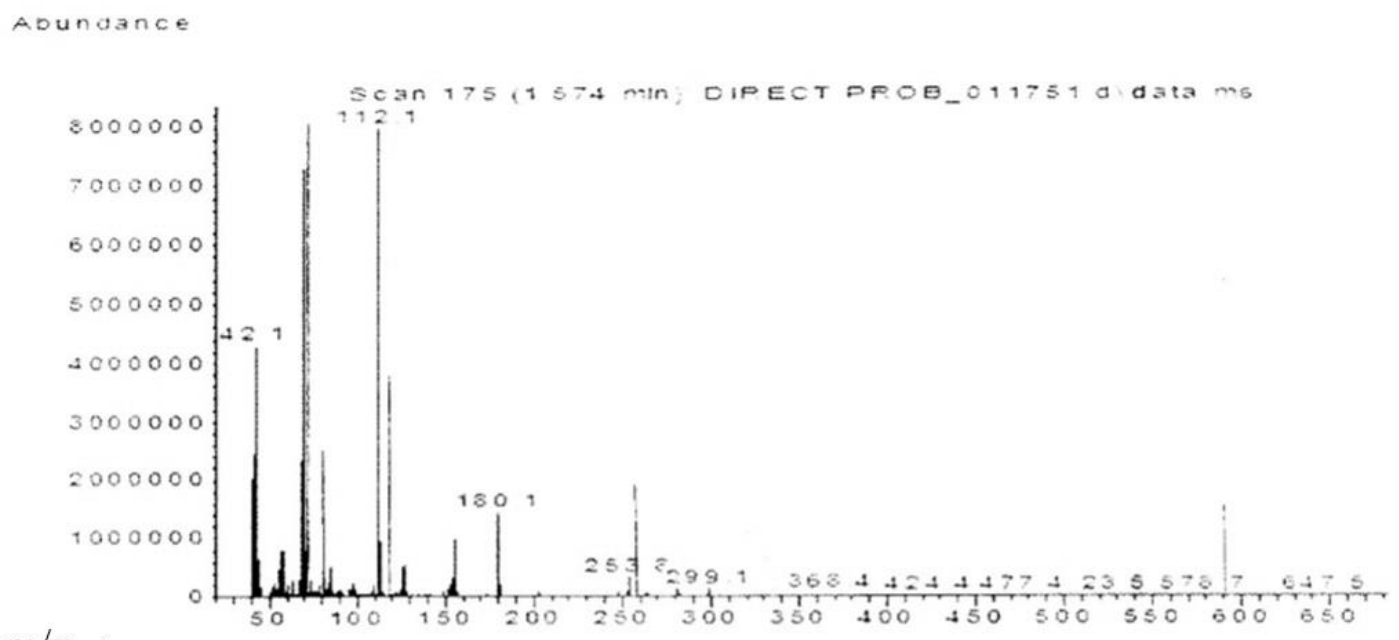

$\mathrm{m} / \mathrm{z} \rightarrow$

Fig. 8. Mass spectrum of $\mathrm{La}^{+3}$ - complex

\section{Biological study:}

The conclusion gained into antibacterial and antifungal experience models studies through agar good diffusion bioassay detect biological activity to the metal salts, ligands and metal complexes after $24 \mathrm{~h}$ in Table 6 and Figure 9. In situation of Ura the antibacterial activity at E.Coli is higher activity like contrast to metal (III) salts, but Phen has a higher activity with E.Coli as compared to Ura, metal ions and metal complexes.

In case of the metals complexes, $\mathrm{Fe}^{+3}$ and $\mathrm{Cr}^{+3}$ - complexes shows higher inhibtion area of $18 \mathrm{~mm}$ with Staphylococcus and E.Coli respectively, as compared to the metal salts, free ligands and other complexes. Phen and $\mathrm{La}^{+3}$-complex that increased the value of inhibition of growth than were during the 24 hours.

In the case of Candida that represent a class of fungi type of yeast that has a clear impact with Phen and less effect with each of $\mathrm{FeCl}_{3}, \mathrm{LaCl}_{3}$ and $\mathrm{La}^{+3}$ complex, with no effect with the rest.

The consequences of biological checking reference that in several complexes are more effective than free ligands, increased activity of the complexes can exist, illustrated at the fundamental in chelation theory [37] .

Table 6: Displayed the Inhibition Circle Dimeter at Millmiter into the Bacteria After $24 \mathrm{~h}$

\begin{tabular}{|c|c|c|c|c|c|}
\hline Compounds & $\begin{array}{c}\text { Bacillus } \\
\text { (G+ev) }\end{array}$ & $\begin{array}{c}\text { Staphylococcus } \\
(\mathbf{G}+\mathrm{ev})\end{array}$ & $\begin{array}{c}\begin{array}{c}\text { Pseudomonas } \\
\text { (G-ev) }\end{array} \\
\end{array}$ & $\begin{array}{l}\text { E. Coli } \\
\text { (G-ev) }\end{array}$ & $\begin{array}{c}\text { Candida } \\
\text { (Yeast) }\end{array}$ \\
\hline Control (DMSO) & 5 & 5 & 6 & 5 & 0 \\
\hline $\mathrm{CrCl}_{3} .6 \mathrm{H}_{2} \mathrm{O}$ & 9 & 12 & 13 & 15 & 0 \\
\hline $\mathrm{FeCl}_{3}$ & 7 & 12 & 11 & 11 & 12 \\
\hline $\mathrm{LaCl}_{3} .7 \mathrm{H}_{2} \mathrm{O}$ & 12 & 0 & 11 & 15 & 13 \\
\hline Uracil & 0 & 11 & 11 & 16 & 0 \\
\hline 1,10-Phen hydrate & 9 & 16 & 13 & 14 & 14 \\
\hline Cr-complex & 9 & 17 & 15 & 18 & 0 \\
\hline Fe-complex & 13 & 18 & 0 & 13 & 0 \\
\hline La-complex & 14 & 9 & 0 & 15 & 11 \\
\hline
\end{tabular}




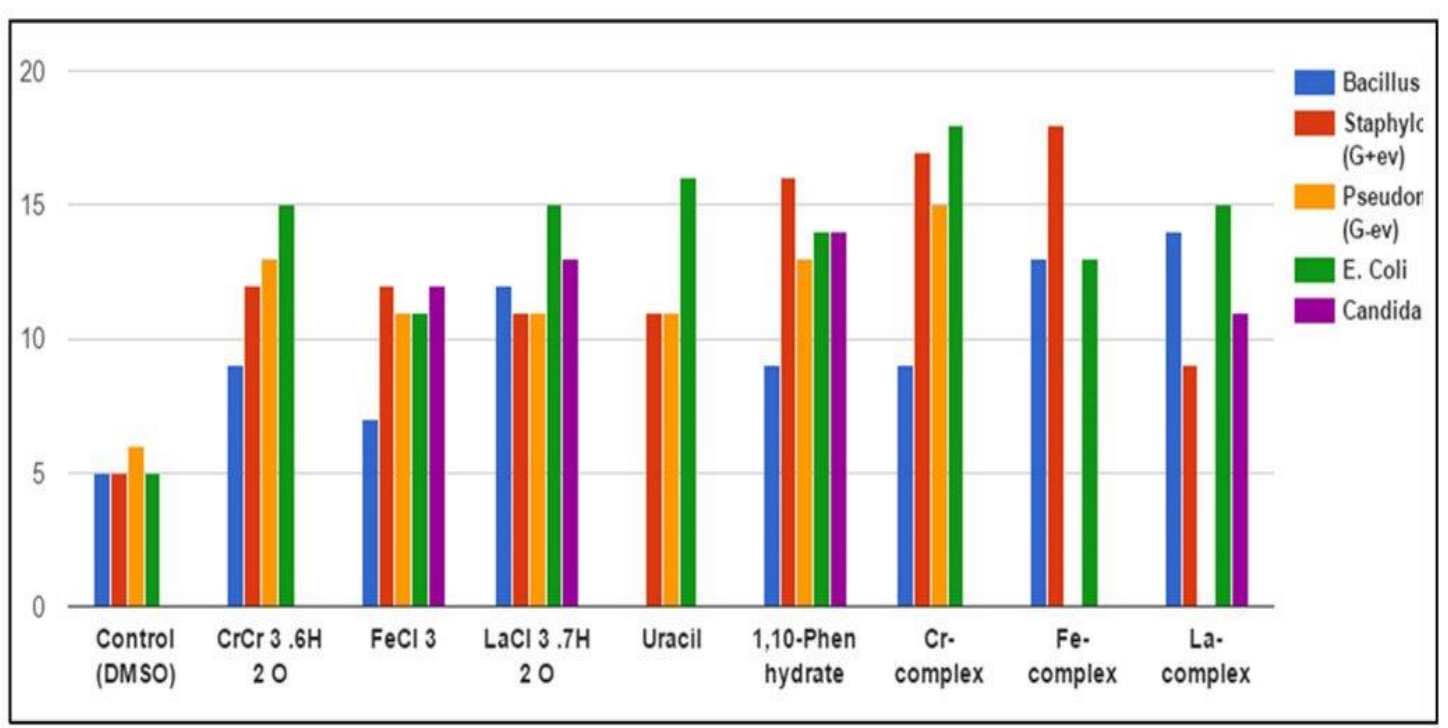

Fig. 9. Shows the Antimicrobial Activity of metal salts and complexes Appear the Inhibition Zones Against Pathogenic Bacteria ( E.coli, Pseudomonas, Streptococcs and Bacillus) and the Antifungal Activity such as Candida( Yeast)

\section{References:}

[1] Morten, HH. N. 2010. A mutant Pfu DNA polymerase designed for advanced uracil-excision DNA engineering. BMD Biotechnology, 10(21):1-7.

[2] Miquel B.-O.; Carolina, E.; Angel, T.;Angel, G.-R., and Antonio F. 2011.RNAs, uracil quaret model with a non-essential metal ion. Chem. Comm. (Camb), 47(16): 4646-4648 .

[3] Igor, P.P.; Levan, M.; Barbara, J.M. and Jill, S.J. 1997. Presence and consequence of uracil in preneoplastic DNA from folate/methyl-deficient rats. Carcinogenesis, 18(11):2071-2076.

[4] Ronald, B. 2015. Potential antineoplastic structural variations of uracil mustard (uramustine) retaining cytotoxic activity and drug-likeness suitable for oral administration. IJC International Journal of Cancer,

2(2): 50-58.

[5]Prashansa, A. 2016. Non-coding ribonucleic acid: a new anticancer drug target. J Pharmacovigil, 4(3):1-2.
[6]Rastogia, V. K. and Alcolea, P. M. 2011. Vibrational spectra, tautomerism and thermodynamics of anticarcinogenic drug:5Fluorouracil. Spectrochim. Acta A Mol Biomol Spectrosc.,79(5):970977.

[7]Helios, K.; Wysokinski, R.; Zierkiewicz, W.; Proniewicz, L. M. and Michalska, D. 2009. Unusual noncovalent interaction between the chelated $\mathrm{Cu}$ (II) ion and the $\pi$ bond in the vitamin $\mathrm{B}_{13}$ complex,cisdiammine(orotato)copper(II):

theoretical and vibrational spectroscopy studies. J. Phys. Chem. B, 113: 8158-8169 .

[8] Surabhi S.; Shukla, V. P. and Krishna, V. 2016. Percentage distribution and structural elucidation of quaternary metal chelates of proline with IMDA and uracil in aqueous medium. ICAIJ, 11(2):058-064.

[9] Hassan, H. H.; Mohammad, H. ElD.; Nada, S.; Ghassan, S. and Kamal, H.2016.Interactions of some divalent metal ions with thymine and uracil thiosemicarbazide derivatives, J Nucleosides \& nucleotides, 35(5):259-276. 
[10]Sarika, V.; Sarita, S.; Amritphale, S. S. and Satyabrata, D. 2016. Synthesis and characterization of neodymium(III) ternary complex using lansorprazole and uracil as ligands, Asian J. Chem., 28(11):2379-2384 .

[11]Ahmed, K. A- G.; Sahar, M. and Doaa, S. El- D.2011.Platinum 1,10phenanthroline: Photosensitizer for photocatalytic degradation of 4chlorophenol, Eur. J. chem, 2 (1):104-108 .

[12] Natalya, A. G.; Nadezhda, V. S. and Mikhail A. G. 2014. Polymethacrylate colorimetric censor for evaluation of total antioxidant capacity. Procedia Chem., 10:97 - 102.

[13]Djuikom, S.Y.G.; Divine, M.Y.; Rajamony, J. and Moise, O.A. 2016. Synthesis,characterization and antimicrobial properties of cobalt(II) and cobalt(III) complexes derived from 1,10-phenanthroline with nitrate and azide co-ligands, Inorg. Chem., 2:1-16 .

[14]Chandralekaa, S.; Ramyab, K.; Chandramohana,

Dhanasekaranb, Priyadharshinib, Panneerselvamc A. and Antimicrobial mechanism of copper (II) 1,10-phenanthroline and 2,2'bipyridyl complex on bacterial and fungal pathogens, J. of Saudi Chem. Soc.,18(6): 953-962.

[15] Mahasin F. Alias and Maysoon M. AbdulHassan. 2015. Synthesis and Characterization of Some Metal Complexes with their Sulfamethoxazoleand 4,4'-dimethyl2,2'-bipyridyl and study Cytotoxic Effect on Hep-2 Cell Line. Baghdad Sci. J.,12(4):741-752.

[16] Darliane, A. M.; Ligiane, R. G.; Gabriel, S. V.i. M.; Sonia, R.W. L.; Denise, da. G.J. B.; Maria, de. N. C. S.and Letícia, R. T. 2016. Norfloxacin and $\mathrm{N}$-donor mixed- ligand copper(II) complexes: synthesis, albumin interaction, Bioinorg Chem Appl, 2016: 1-11 .

[17] Jacob, SW. and Herschler, R.1986. Cryobiology., 23(1):14-27.

[18] Geary, W. J. 1971. The use of conductivity measurements in organic solvents for the characterization of coordination compounds, Coord. Chem. Rev.7 (1): 81-122.

[19] Rehab AL-H.; Ayad T. Mahmood; Enas Z. Mohamed; Asmaa A. B. Maryoosh and Ali A. R. Hussein. 2016. Synthesis, characterization, theoretical studies and biologIcal activities of mixea ligand complexes of $\mathrm{Cr}(\mathrm{III}), \mathrm{Mn}(\mathrm{II})$, $\mathrm{Fe}(\mathrm{III}), \mathrm{Co}(\mathrm{II}), \mathrm{Ni}(\mathrm{II})$ and $\mathrm{Cu}(\mathrm{II})$ with 2-hydroxybenzaldehyde and oxalic acid, Acta Chim. Pharm. Indica: 6(1):12-25

[20] Masoud, M. S.; Abou Al-Enein, S. A. and Obeid, N. A., Z. 2001. Electronic spectra properties of substituted aryazothiobarbiturate compounds in the presence of different solvents .Z. Phys. Chem., 215(7):867-881.

[21] Ahmed, I. T.; Boraei, A. A. A. and Ibrahim, S. A.1997. Mixed - ligand complexes of some metal ions with $\mathrm{N}$-(2-acetamido)iminodiacetic acid salicylic acid derivatives, synthesis, solution equilibria and characterization studies. Synth. React. Inorg. Met. Org. Chem., 27:169-186.

[22]Susi, H. and Ard, J.S. 1971. Vibrational spectra of nucleic acid constituents-I: planar vibrations of uracil. Spectrochim. Acta A, 27:1549-1562.

[23] Nakamoto, K. 1970. Infrared of inorganic and coordination compounds. Wiley - Interscience, New York, p. 152.

[24] Vahid, A.; Nasser, S.; Hamid, R. K. and Peiman, M. 2007. Iron(III) mixed-ligand complexes: Synthesis, 
characterization and crystal structure determination of iron(III) hetero-ligand complexes containing 1,10-phenanthroline, $2,20-$ bipyridine, chloride and dimethyl sulfoxide, $\quad\left[\mathrm{Fe}(\right.$ phen $) \mathrm{C}_{13}$ (DMSO)] and [Fe(bipy)Cl3(DMSO)]. Polyhedron, 26:4908-4914.

[25] Rehab K. Al-Shemary; Ahmed T. Numan and Eman M. Atiyah. 2016. Synthesis, characterization and antimicrobial evaluation of mixed ligand complexes of manganese(II), cobalt(II), copper(II), nickel(II) and mercury(II) with 1,10phenanthroline and a bidentate Schiff base, Eur. Chem. Bull., 5(8): 335-338.

[26] Narang, K.K.; Singh, V.P. and Bhattacharya, D. 1997. Synthesis, characterization and antitumour activity of uracil and uracilhistidine complexes with metal(III) ions, Trans. Met. Chem., 22: 333337.

[27] Juan,J.F.; Angel,T. and Delfi, M. 1987. Some new derivatives of Co(III) with uracil, uridine and pyrimidine nucleotides. Inorganica Chimica Acta, 135:197-202.

[28] Walaa, H.M.; Mohamed, G.G. and El-Dessouky, M. M.I. 2014. Chemistry, synthesis, characterization and in vitro biological activity of mixed transition metal complexes of lornoxicam with 1,10phenanthroline, Int. J. Electrochem. Sci., 9:1415 - 1438.

[29] Pranita U. Gawande; Mandlik P. R. and Aswar1 A. S. 2015. Synthesis and characterization of $\mathrm{Cr}$ (III), $\mathrm{Mn}(\mathrm{III}), \mathrm{Fe}(\mathrm{III}), \mathrm{VO}(\mathrm{IV}), \mathrm{Zr}(\mathrm{IV})$ and $\mathrm{UO}_{2}(\mathrm{VI})$ complexes of Schiff base derived from isonicotinoyl hydrazine, Indian J Pharm Sci., 77(4): 376-381.

[30] Michael J. Carney; Nicholas J. Robertson; Jason A. Halfen; Lev N.
Zakharov and Arnold L. Rheingold. 2004. Octahedral Chromium (III) Complexes Supported by Bis(2pyridylmethyl) amines: Ligand Influence on Coordination Geometry and Ethylene Polymerization Activity, Organomet., 23 (26): 6184-6190.

[31]Rehab Al-H.; Ayad T. Mahmood; Enas Z. Mohamed; Asmaa A. B. Maryoosh and Ali A. R. Hussein. 2016. Synthesis, characterization, theoretical studies and biological activities of mixed ligand complexes of $\mathrm{Cr}(\mathrm{III}), \mathrm{Mn}(\mathrm{II})$, $\mathrm{Fe}(\mathrm{III}), \mathrm{Co}(\mathrm{II}), \mathrm{Ni}$ (II) AND Cu(II) with 2-hydroxybenzaldehyde and oxalic acid, Acta Chim. Pharm. Indica: 6(1), 12-25.

[32] Aida L. El-Ansary and Nora S. Abdel-Kader. 2012. Synthesis, characterization of $\mathrm{La}(\mathrm{III}), \mathrm{Nd}(\mathrm{III})$, and Er(III) complexes with Schiff bases derived from benzopyran-4one and thier fluorescence study, Int.J.Inorg.Chem.,2012:1-13.

[33]Anshu S. 2011. Synthesis and structural investigations of coordination compounds of palladium (II) with uracil, uracil 4-carboxylic acid 4-aminouracil, J.Biosci Tech., 2(1): 213-219.

[34] Iman, M. M. Hasan and Sanaa, H. S. 2013. Synthesis and characterization of come new phenolic Schiff bases derivatives. Baghdad Sci. J.,10(2):377-387.

[35] Gehad, G. M.; Mohamed, M. O. and Ahmed, M. H. 2006. Metal Complexes of Schiff Bases: Preparation, Characterization, and Biological Activity, Turk J Chem, 30:361 - 382.

[36]Bottega, F. C.; Oliveira, M.R.L.; Garcia, C. V.; Menezes, D. C.; Rubinger, M.M.M. and Zambolim, L. 2013. Synthesis characterization and antifungal activity of tris $(1,10$ - 
phenanthroline) iron (II) bis(N-Rsulfonyldithiocarbimate) zincate(II). Quim. Nova, 36: 803-807.

[37] Sarika, V.; Sarita, S. and Poonam, R.2011. Anti microbial study of newly formed complexes of transition and inner transition metals with antiulcer drug and RNA bases, Der Pharma Chemica, 3(2): 468-475.

\section{تحضير ودراسة طيفية وفعالية بايولوجية لمعقدات ثلاثية التكافؤ حاوية على كاندات مختلطة من اليوراسيل و 10,1- فينانثرولين شذى محمد حسن عبيد}

قسم الكيمياء، كلية التربية للعلوم الصرفة / إن الهيثم، جامعة بغداد، بغداد، العر اق.

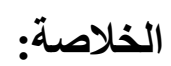

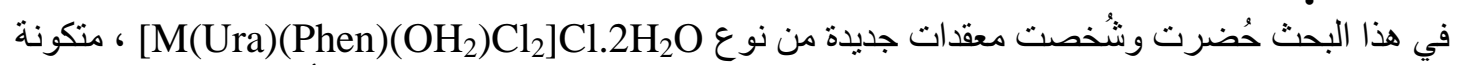

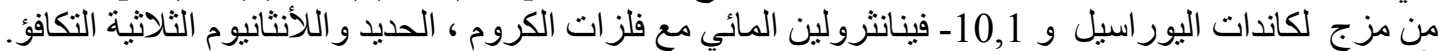

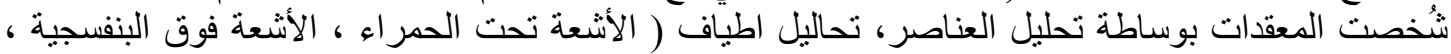

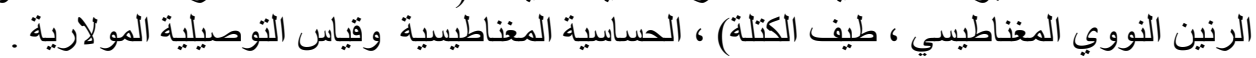

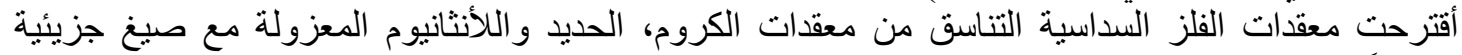

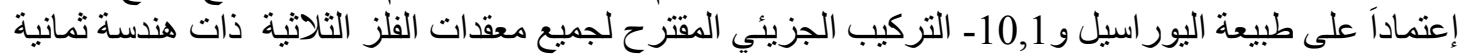

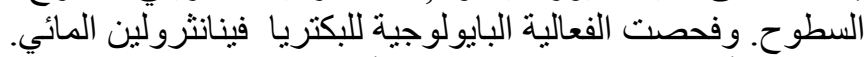
المسبية للأمر اض وفعالية الفطريات لأملاح الفلز الثلاثية ، اللكاندات ومعقدات الفلز الثلاثثة الني تمت دراستها ـ. الكلمات المفتاحية : اليور اسيل، 1,10- فينانثرولين المائي، معقدات الفلز، دراسات طيفية، فعاليات بايولوجية . 